\title{
Lockdown texts
}

\section{Des Fitzgerald ${ }^{1}$ Richard Ashcroft ${ }^{2}$ - Greg Hollin ${ }^{3}$ - Katrina Karkazis ${ }^{4}$. Nicholas B. King ${ }^{5}$ Hannah Landecker ${ }^{6}$ Nicolas Langlitz ${ }^{7}$. Filippa Lentzos ${ }^{8}$. Todd Meyers ${ }^{9} \cdot$ Jörg Niewöhner $^{10}$ • Carlos Novas $^{11} \cdot$ Anne Pollock ${ }^{8}$. Nikolas Rose $^{8}$ - Chloe Silverman ${ }^{12}$ - Hallam Stevens ${ }^{13}$ - Banu Subramaniam ${ }^{14}$. Ayo Wahlberg ${ }^{15}$ - Elizabeth A. Wilson ${ }^{4}$}

\section{Introduction}

\section{Des Fitzgerald}

In the center of a pandemic, at a time of major contraction in the global higher education 'industry,' when many colleagues are struggling with illness, grief, care, unemployment, new and impossible work demands—book reviewing, as a very particular,

$\checkmark$ Des Fitzgerald

p.d.fitzgerald@exeter.ac.uk

1 Wellcome Centre for Cultures and Environments of Heath, University of Exeter, Exeter, UK

2 City Law School, City, University of London, London, UK

3 School of Sociology and Social Policy, University of Leeds, Leeds, UK

4 Department of Women's, Gender, and Sexuality Studies, Emory University, Atlanta, USA

5 Department of the Social Studies of Medicine, McGill University, Montreal, Canada

6 Institute for Society and Genetics, University of California, Los Angeles, Los Angeles, USA

7 Department of Anthropology, The New School for Social Research, New York, USA

8 Department of Global Health and Social Medicine, King's College London, London, UK

9 Department of Social Studies of Medicine, McGill University, Montreal, Canada

10 Institute of European Ethnology, Humboldt-Universität zu Berlin, Berlin, Germany

11 Department of Sociology and Anthropology, Carleton University, Ottawa, Canada

12 Center for Science, Technology \& Society and Department of Politics, Drexel University, Philadelphia, USA

13 School of Humanities, Nanyang Technological University, Singapore, Singapore

14 Women Gender, Sexuality Studies, University of Massachusetts, Amherst, Amherst, USA

15 Department of Anthropology, University of Copenhagen, Copenhagen, Denmark

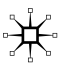


and yet (to administrative machinery) invisible, scholarly genre, is unlikely to be at the top of many people's to-do lists. We thus suspend our usual book review forum for this issue, and turn to a different way of thinking about what we might do with reading in pandemic times. In the following section, we have asked members of the BioSocieties editorial board, plus some other colleagues and friends, to tell us what they've been reading — scholarly or otherwise, instructive or not—during the period that has come to be known as 'lockdown' in many countries. The act of reading during a pandemic, of course, of having and taking time to read, is its own privilege and not always a comfortable one, as health, retail, maintenance and may other workers keep the world turning. Nonetheless, the texts we think though here are deeply embedded in the social, political, and biological present; the act of reading and writing about them, we hope, still help to diffract that present in some original and useful ways.

\section{What I Haven't Been Reading During the Pandemic}

\section{Richard Ashcroft}

City Law School, City, University of London, London, UK

\section{richard.ashcroft@city.ac.uk}

I haven't been reading AW Moore's The Evolution of Modern Metaphysics. I haven't been reading Mark Fisher's K-Punk. I haven't been reading Alison Bechdel's The Essential Dykes to Watch Out For. I haven't been reading GW Treitel's An Introduction to the Law of Contract. I haven't been (re)reading Wittgenstein's Philosophical Investigations. These modern masterpieces each have bookmarks a few pages in and a thin film of dust, as they sit, unread. So much for good intentions. So much for all this time freed up for self-improvement. On the other hand, I haven't been reading Ed Byrne and Charles Clarke's The University Challenge. Sometimes giving up is not a defeat, but self-care.

More importantly, I haven't been reading much bioethics.

This is the moment for infectious disease epidemiologists, delivery drivers, intensivists, sociologists... It should be the moment for bioethicists. Some of my peers certainly have embraced it. But I am not comfortable in this moment for my field.

The source of my discomfort is this: Now, more than ever, citizens, scientists, policy makers, politicians would like some certainty about what to do. There are some things we know; there are an awful lot of things we don't; there may be quite a lot of things we can't. In this moment the idea that there is a specialist body of knowledge which will tell us how to do the right thing is very attractive. Bioethics looks as if it could be that specialist body of knowledge. But it isn't.

First of all, though bioethics as a field has concentrated on many things, it has generally neglected infectious diseases, large-scale resource allocation problems, social inequalities, and other central features of this pandemic. That's not to say 
that some bioethicists have not tackled these things, but as a whole the field has not absorbed them.

Secondly, the ways that bioethics solves its intellectual problems, as a field, depend very much on a very narrow range of tools and concepts-individual rights, utilitarian calculations, procedural justice. Again, this is not true across the board (feminist bioethicists, for instance, would reject it). But it characterizes the mainstream pretty well. And yet, on inspection, these methods turn out not to have been much help dealing with the social, structural, institutional problems the pandemic presents.

There have been a lot of articles written during this period by bioethicists, yet I have not been reading them. The sort of spurious clarity and certainty involved in writing so much, so fast, filled me with distaste. I don't reject the good intentions or the wish to be helpful. But I do distrust the form that helpfulness has taken.

It seems to me that what bioethics could usefully have done-might usefully still do-is to contribute to helping us live with uncertainty. To challenge the way certain questions were framed. To undo spurious certainty. To clear the ground.

So no, I haven't been reading Wittgenstein. But I rather wish others had.

Richard Ashcroft is Professor of Bioethics and Deputy Dean of City Law School at City, University of London.

\section{The Most Important of the Unimportant Things}

\section{Greg Hollin}

School of Sociology and Social Policy, University of Leeds, Leeds, UK

\section{G.Hollin@Leeds.ac.uk}

In recent years, there has been increasing worry that concussive blows to the head experienced during sport may result in long-term neurological damage: a highprofile article in JAMA, for instance, found evidence of a neuropathology known as Chronic Traumatic Encephalopathy (CTE), which in advanced cases has Alzheimerlike symptoms, in the brains of 110 out of 111 ex-National Football League (NFL) players (Mez et al., 2017). Just as worryingly, a study in the NEJM hinted that subconcussive blows - from heading a soccer ball, for instance-might also substantially increase rates of dementia (Mackay et al., 2019). This summer, I should have been following the exploits of an amateur American football team, part of a threeyear project examining communities' responses to, and understanding of, these questions of concussion and neurodegenerative disease in sport.

There's not a lot of sport being played at the moment, though, and American football in the UK is no exception: in mid-May the season was summarily canceled by the sport's governing body. See you all in 2021. My circumstances may be peculiar, but I am not alone in saying that my experience of 'lockdown' is being shaped not only by the emergence of this new virus but also, and quite radically, by the absence of sport. 
The rhythm of the week, the day even, is disrupted by the absence of what Pope John Paul II-allegedly a supporter of Fulham — apparently called the most important of all the unimportant things.

I've tried to fill the Sundays I should be spending observing sports by reading about them instead: Against Football (Almond, 2014); Dixieland Delight (Travis, 2007); End Zone (DeLillo, 1972), Junior Seau (Trotter, 2015); One Game at a Time (Hern, 2013); The Blind Side (Lewis, 2007); The Fight (Mailer, 2000/1975). These books all reviewed at least moderately well in the popular press and, in some cases at least, have a whiff of ethnography about them. (Indeed, part of my motivation for reading The Blind Side was that in Tales of the Field (2011, p. 181), anthropologist John van Maanen asserts surprisingly forcefully that Michael Lewis does not write ethnography.) And while the reading might not replace fieldwork, it's certainly been interesting.

First, reading these books has reminded me about the many raced, classed, and gendered problems with sport which, in a macro-sociological sense, are not always foregrounded during fieldwork. These books are all by men, about men, and more or less explicitly for men. They all originate from North America. They are largely, although not exclusively, by white men from the coasts and about men of color from the interior and the south. A minority of them feature passages that are overtly misogynistic and homophobic.

The books also remind me of the importance of sport, that sport cannot simply be subtracted, stopped, or deemed irrelevant, without significant effect on a wide array of identities, communities, and meanings. In Beyond a Boundary, discussing the place of famed Victorian cricketer W.G. Grace within social history, CLR James says:

I can no longer accept the system of values which could not find in these [history] books a place for W.G. Grace... Between those who, writing about social life in Britain, can leave him out, and myself, there yawns a gulf deep and wide.

(James, 2005, p. 208)

In other words, to write the social history of Britain without explicitly accounting for the emergence of a new type of sporting superstar- "the best-known Englishman of his time" (ibid) — and, indeed, a new type of sport, is to spectacularly miss something about the society being chronicled.

James's argument applies readily to our present moment: sport, and its absence, may be an unimportant thing in the grand scheme of the self-evidently important thing that is COVID-19 but it needs to be figured into the mix. As a propaganda tool; an interlocking series of multi-billion industries; a labor-relations issue; or simply a way to get out of (or tolerate being in) the house, sport is an intractable part of our present situation and to ignore that would be to miss something crucial.

\section{References}

Almond, S., 2014. Against Football: One Fan's Reluctant Manifesto. Melville House, New York \& London. 
DeLillo, D., 1972. End Zone. Picador.

Hern, M., 2013. One Game at a Time: Why Sports Matter. AK Press, Edinburgh, Oakland, and Baltimore.

James, C., 2005. Beyond a Boundary. Yellow Jersey Press, London.

Lewis, M., 2007. The Blind Side. W.W. Norton \& Company, New York \& London.

Mackay, D.F., Russell, E.R., Stewart, K., MacLean, J.A., Pell, J.P., Stewart, W., 2019. Neurodegenerative disease mortality among former professional soccer players. N Engl J Med NEJMoa1908483. https://doi.org/10.1056/NEJMoa1908483

Mailer, N., 2000. The Fight. Penguin Classics, London.

Mez, J., Daneshvar, D.H., Kiernan, P.T., Abdolmohammadi, B., et al. Clinicopathological Evaluation of Chronic Traumatic Encephalopathy in Players of American Football. JAMA 318, 360-370. https://doi.org/10.1001/jama.2017.8334

Travis, C., 2007. Dixieland Delight: A Football Season on the Road in the Southeastern Conference. It Books, New York.

Trotter, J., 2015. Junior Seau: The Life and Death of a Football Icon. Houghton Mifflin Harcourt, Boston and New York.

van Maanen, J., 2011. Tales of the Field: On Writing Ethnography, 2nd ed, Chicago Guides to Writing, Editing, and Publishing. The University of Chicago Press, Chicago and London.

Greg Hollin is Wellcome Research Fellow in Humanities and Social Sciences, at the School of Sociology and Social Policy, University of Leeds

\section{Grave Concerns}

\section{Katrina Karkazis}

Department of Women's, Gender, and Sexuality Studies, Emory University, Atlanta, USA

katrina.karkazis@emory.edu

As SARS-CoV-2 reached pandemic proportions earlier this year, and COVID-19, the disease it causes, began to kill so many, research emerged confirming what many had already observed with grave concern-that underlying chronic conditions, most associated with poverty and discrimination, increase risk of disease severity. My mind immediately turned to Julie Livingston's deeply moving 2012 ethnography of a cancer ward at Princess Marina Hospital, in Gaborone, Botswana, a book I had recently taught in a class on medicine and power. In Improvising Medicine, Livingston critiques the widely accepted "epidemiological transition" theory, proposed in 1971, which holds that as a society "modernizes," making gains in various economic and social indicators, the "distribution" of disease and death shift from epidemics of infectious diseases toward chronic degenerative diseases. 
The gut-wrenching stories Livingston tells from the oncology ward show something far more complicated: that the separation of diseases into the distinct stages and types that the "epidemiological progress narrative" depended on-STI vs. cancer, infectious vs. chronic, "diseases of poverty" vs. "diseases of affluence"-was fuzzy rather than neat, precarious rather than inevitable. As she writes, models of epidemiological transition, which take "development" as their temporal telos, are illsuited to fully capturing changes in disease burdens. And so, while Botswana's public health efforts had long focused on "pre-transition" issues like infectious disease, malnutrition, and childbirth, a cancer epidemic was silently taking hold. The cancers turn out to be facilitated by and synergistic with endemic infectious diseases, especially HIV/AIDS — and, curiously, its treatment — that rendered bodies susceptible to cancers, a fact that also escaped notice because of the "conceptual impossibility" of cancer in Africa.

A similar phenomenon, whereby the infectious is mutually imbricated with the chronic, is taking place now with the COVID-19 pandemic, as it unfolds in the United States. Livingston herself recently discussed the analogous role of comorbidity shared by both epidemics in an interview in the Los Angeles Review of Books. Multiple hospital-based studies have revealed a very high percentage of hospitalized COVID-19 patients with severe illness as having at least two or more comorbidities, the most prevalent of which are hypertension and diabetes. Whereas cancer in Botswana was precipitated by infectious disease, chronic disease in the U.S. and other industrialized nations has been a deadly accelerant for infectious disease, exposing the other side of the same wretched coin.

But these numbers don't tell the whole story: in numerous studies the majority of the critically ill-up to $80 \%$ - were either Black or Latino. In the United States, Black people have more, and graver degrees, of the underlying chronic conditions that worsen COVID-19: hypertension, heart disease, diabetes, stroke, and asthma. Overall, poor people of color are far more likely to be hospitalized, to have a serious case, and/or to die from COVID-19. The pandemic has also devastated tribal nations where, for example, infection and death rates among the Navajo Nation have been as much as 10 times higher than in the neighboring states of Utah, Colorado, Arizona, and New Mexico.

In Washington, DC, National Public Radio reported that there are at least five Black deaths for every white one. Similar disparities have been documented across the entire U.S., reminding us of poet Claudia Rankine's observation that "Dead blacks are a part of normal life here."

Just as Livingston conjoins cancer in Botswana with the country's broader political economies-those that leave the Batswana vulnerable-so, too, must COVID-19 be similarly conjoined. COVID-19 is disproportionately killing people who live in complex and deeply entrenched ecosystems of disparity, environments characterized by long-standing material resource deprivation caused by economic inequality and racial discrimination. Recognizing these comorbidities and their relationship to these ecosystems is crucial in the context of this pandemic because of the 
overrepresentation of people of color in the essential, front-line jobs that put them in proximity to the virus.

White acceptance of Black and brown death is, of course, not new. But this is the challenge COVID-19 presents: once there is a vaccine or a treatment and this pandemic is "over," how does Black and brown death become as intolerable as white death? Inextricably linked to "the still unfolding aftermaths of Atlantic chattel slavery," as Christina Sharpe notes, the insistent neglect and violence that render these premature deaths as normative across the U.S., risk ongoing, indefinite rationalization. "This is how you are a citizen," Claudia Rankine writes. "Come on. Let it go. Move on." But moving on is not to be confused with moving past, she reminds, as "The past is a life sentence, a blunt instrument aimed at tomorrow."

\section{References}

Livingston, Julie. (2012) Improving Medicine: An African Oncology Ward in an Emerging Cancer Epidemic. Durham, NC: Duke University press

Rankine, Claudia. (2014). Citizen: An American Lyric. Minneapolis: Graywolf Press

Rankine, Claudia. (2015). "The Condition of Black Life is One of Mourning." New York Times, June 22

Katrina Karkazis is Visiting Professor of Women's, Gender, and Sexuality Studies et Emory University and a Senior Research Fellow with the Global Health Justice Partnership at Yale University

\section{Catastrophe Theory in Slow Motion}

\section{Nicholas B. King}

Department of the Social Studies of Medicine, McGill University, Montreal, Canada nicholas.king@mcgill.ca

I've returned to J.G. Ballard, whose work I hadn't read in well over a decade, during the COVID-19 pandemic. The news resonates with details that would find themselves at home in Ballard's novels and, especially, his short fiction. Passengers confined indefinitely on a luxury cruise ship. People panic-buying toilet paper at the first hint of future privation. A virus irremediably changing social mores. American citizens, distracted by constant updates from their senescent president, fail to fully appreciate a brewing national crisis. Barred from physical interaction, humans retreat into their homes and interact only through screens. Previously normal activities-shopping, walking, interacting - acquire an unreal sheen. Time fractures, dilates, liquifies, loses meaning. Space constricts and we retreat inward, into our homes, into our selves. 
I think most of the unnamed astronauts producing their "Report on an Unidentified Space Station" (2014). The structure is small, their stay will be short. They are puzzled by the station's immense gravitational field, but consider themselves "fortunate to have found safe haven at a moment when the expedition was clearly set on disaster." The repairs take longer than anticipated. They begin to explore the station. Their initial projections were wrong; it is far larger than it first seemed. It consists only of immense, undifferentiated, empty concourses, way stations for long-departed travelers. They lose track of time and their estimation of the station's size expand. Their departure point is forgotten; the station interior is "coeval with the cosmos." A brief stopover has metastasized into a new permanence: "Despite our steady passage we sense that we are not moving at all, and may well be trapped within a small waiting room whose apparently infinite dimensions we circle like ants on a sphere."

Ballard never meant the galactic holding area as a metaphor for interminable pandemic quarantine, but it nevertheless strikes a chord. A chronicler of the razor-thin liminal space between primal inner urges and a screen-dominated, fully mediatized public sphere, Ballard has since the 1960s been heralded-for better and for worseas 'visionary.' The term often applies to totalizing dystopian visions; think George Orwell, Yevgeny Zamyatin, Margaret Atwood. Ballard was not a world-builder, however. He wrote snapshots of an emerging mediasphere. These images, myths of the near future, dormant for so long, continue to materialize, mutated, recombined, like a virus.

\section{References}

Ballard, JG. (2014) 'Report on an Unidentified Space Station" in The Complete Short Stories, Vol.2. London: Fourth Estate

Nicholas B. King is an Associate Professor in the Department of the Social Studies of Medicine at McGill University.

\section{The Literature of the Underlying Condition}

\section{Hannah Landecker}

Institute for Society and Genetics, University of California, Los Angeles, Los Angeles, USA

\section{landecker@soc.ucla.edu}

For someone used to diving into the scientific literature and readily gaining a feeling of understanding more, reading the voluminous, rapidly produced medical and molecular research on Covid-19/Sars-COV-2 has been rather the opposite-a profusion of puzzle pieces, without a clear sense that they are all produced from the same jigsaw. Perhaps in an anxious reach for a thread to follow, I have been 
following the underlying condition rather than the virus. Studies of patients in China and Europe first highlighted underlying conditions-particularly metabolic disorders such as diabetes - as an indicator of vulnerability to more severe illness and death with Covid-19; soon after stark socioeconomic and racial disparities in the mortality and morbidity from Covid-19 were being explained in terms of prevalence of underlying conditions.

And then, in May, came the death of George Floyd in Minneapolis, and the initial reporting of the autopsy highlighting his cardiovascular state as an underlying cause of death, as if the world had not seen him being asphyxiated. In what a group of physicians has called a "weaponization of medical language," one that used Floyd's anatomy against himself, they write that the underlying condition has become a form of gaslighting (Crawford-Roberts et. al. 2020).

The background becomes the foreground, and I am left asking: what is an underlying condition? I am reading and in many cases re-reading anew in light of this question. There is a true forest of vocabulary in the health and human sciences for how things intersect-comorbidity, intersectionality, predisposition, syndemics, structural violence, allostatic load, biosocial, biocultural-but each of these, in its own way, seems to fall short of rendering the profound historicity of the bodies in which viral violence is occurring today. So here's a fragment of my underlying condition reading list, still very much under development: Anthony Hatch's 2016 Blood Sugar: Racial Pharmacology and Food Justice in Black America, because it helps us understand both the historical materiality of the underlying condition and the political race work that concepts of dysfunction do; Adam Dickinson's Anatomic, because he might be the poet of the underlying condition, using "the hormone as a compositional method, with its emphasis on concentration, cascade and sequence"-and, I would add, using the endocrine disruptor and the heavy metal and other anthropogenic cellular legacies as compositional method (2018, 145). Jonathan Crary's 24/7 (2013), because sleep is, or should be, a social justice issue too. Elizabeth Hoover's The River is in Us: Fighting Toxics in a Mohawk Community (2017), because it foregrounds a different sort of biochemical compositional method, full of thinking life and what is "in us" after the industrial sedimentation of polychlorinated biphenyls (PCBs) in traditional foodways, and industrial foodways in cultural bodies. There are many more, but it's a start.

\section{References}

Crary, Jonathan. (2013). 24/7: Late Capitalism and the Ends of Sleep. London: Verso

Crawford-Roberts, A. et. al. (2020). "George Floyd's Autopsy and the Structural Gaslighting of America," Scientific American https://blogs.scientificamerican.com/ voices/george-floyds-autopsy-and-the-structural-gaslighting-of-america/

Dickinson, A. (2018). Anatomic. Toronto: Coach House Books.

Hatch, A. (2016). Blood Sugar: Racial Pharmacology and Food Justice in Black America. Minneapolis. MI: Minnesota University Press 
Hoover, E. (2017). The River is in Us: Fighting Toxics in a Mohawk Community. Minneapolis. MI: Minnesota University Press

Hannah Landecker is Director of the Institute for Society and Genetics at UCLA

\section{Shipwrecked with Blumenberg amid a Microbial Superstorm}

\section{Nicolas Langlitz}

\section{Department of Anthropology, The New School for Social Research, New York, USA}

\section{LanglitN@newschool.edu}

It was a beautiful spring day when The New School decided to close its New York campus amid a microbial tsunami. Right in time, my family had escaped from Brooklyn, which emerged as the epicenter of the epicenter of the SARS-CoV-2 pandemic in the United States, to a leafy New Jersey suburb where our fellow whitecollar workers celebrated the fact that they no longer had to commute to the city by taking a walk in the park. The scene made me think of the early days of World War I when many Europeans enthusiastically embraced the looming disaster: "Finally, something happens!"- only that, in the commuter belt of the city that never sleeps, this holiday mood felt more like: "Finally, nothing happens!"

Of course, the calm before the storm didn't last long. As Brooklyn's Prospect Park turned into a field hospital and the Bronx dug out mass graves, I put aside the New York Times and re-read Hans Blumenberg's Shipwreck with Spectator. This booklet, first published in 1979, traces the metaphor of shipwreck through the history of philosophy. It contributed to the author's project of what he calls a "metaphorology," examining the non-conceptual underbelly of philosophical thought. But I returned to it because of the metaphor of the shipwreck itself: I had also become a spectator who observes the distress of those at sea from the safety of dry land. This was precisely the place of theoria in ancient Greek philosophy. I didn't lack compassion for those drowning in their own body fluids in a cytokine storm, but, like Montaigne, I felt pleasure that one of my useless qualities, the ability to be a spectator of an event I could not prevent, helped me and my family to survive (p. 17).

Having survived the Holocaust as what the Nazis called a Half-Jew, Blumenberg was no stranger to the pleasures of self-preservation. At a time when his colleagues almost unanimously agreed that the subject-object dichotomy was among the great evils of modernity, he defended the existential importance of detachment. In recent years, the tendency to emphasize our interconnectedness with the microbial world has endowed parts of science studies with an almost mystical quality. Shipwreck with Spectator offers an untimely perspective on the difference the present introduces with regard to the past. In antiquity, seafaring symbolized a transgression of natural boundaries that invited disaster. By contrast, anthropologist Tobias Rees (2020), among others, has articulated a new cosmology in which a multispecies configuration of viruses, animal hosts, and humans will no longer seem like an illegitimate transgression as humans come to realize that they have 
always been part of the outside. With a PDF of Blumenberg on my iPad (the hardcopy could not be retrieved from my closed Manhattan office), I preferred biosocial distancing to a swim in the churned-up ocean of viruses.

Unfortunately, it didn't take long for other uses of the shipwreck metaphor to resonate as well. Within a week of its closure, the university ran into heavy seas and as department chair I could not observe the spectacle from the shore but had to participate in an onslaught of emergency Zoom meetings. Our faculty salaries were cut, pension contributions eliminated, and this was only the first ballast that the administration shed as it began to reconstruct the ship on the open sea to prevent it from sinking. Considering that the COVID pandemic has become a moment of truth, not only for higher education, future-oriented readers might want to note Blumenberg's short book, and read about modern uses of a metaphor that would eventually abandon imagery of dry land and safe harbors, to prepare us for "living with shipwreck" indefinitely (p. 73).

\section{References}

Blumenberg, H. (1997/1979) Shipwreck with Spectator. Paradigm of a Metaphor for Existence. Cambridge (MA): MIT Press.

Rees, T. (2020) From The Anthropocene To The Microbiocene. Noēma (1), https ://www.noemamag.com/from-the-anthropocene-to-the-microbiocene/.

Nicolas Langlitz is an Associate Professor at The New School for Social Research in New York

\section{Biopower and Precision Surveillance}

\section{Filippa Lentzos}

Department of Global Health and Social Medicine, King's College London, London, $U K$

\section{filippa.lentzos@kcl.ac.uk}

Biology's intersection with artificial intelligence (AI) holds unprecedented potential for magnifying Michel Foucault's notion of biopower. Global responses to the pandemic have crystallized how quickly and readily machines, algorithms, 
and computing power can be adopted into techniques for achieving the subjugation of bodies and the control of populations.

As the Chinese city of Wuhan went into lockdown, the authorities carried out large-scale remote temperature measurements of households in apartment complexes through drones equipped with infrared cameras. Drones were also used to patrol public places, tracking whether people were traveling outside without face masks or violating other quarantine rules. Chinese police forces debuted augmented reality (AR) smart glasses powered by AI capabilities designed to recognize individuals with potential COVID-19 symptoms. The glasses have facial recognition capability to identify and profile individuals in real time, and can also record photos and videos. As Wuhan started to open up again, 'Health Code' was introduced, an app the authorities required people to use when entering and exiting residential areas, supermarkets, subways, and taxis among other spaces. The app stores your personal information, including your ID number, where you live, whether you have been with people carrying the virus, and their symptoms. As you touch in or out on entering or exiting, the app gives you a colour: green means you can go anywhere, yellow means you have to quarantine for 7 days, red for 14 days. The app also surreptitiously collects - and shares with the police-your location data. ${ }^{1}$

Beyond these interventions, and in a range of countries, we are seeing intrusive and coercive forms of surveillance and use of personal data more familiar to us from dystopian novels like Nineteen Eighty-Four and Brave New World. As other countries went into lockdown, surveillance cameras with facial recognition tracked quarantine evaders or gauged elevated temperatures of potentially infected individuals in crowds. Fine-grained location data transmitted from mobile phones determined how many people were obeying lockdown orders, fever-detecting cameras screened travelers arriving at airports, and algorithms monitored social media posts for signs of COVID-19's spread. Contact-tracing apps, centrally storing user interactions, provide 'social graphs' of who you have physically met over a period of time. 'Immunity passports' or 'risk free certificates' combine facial recognition technology with COVID-19 testing and medical records. ${ }^{2}$

To make sense of this trajectory, I turned to Eleonore Pauwels' 2019 policy brief for the United Nations on AI and converging risks. Developing an evidencebased scenario for understanding ways in which AI, affective computing, genomics and neuro-technologies can converge, Pauwels delineates how biosensors and algorithms will capture and analyze an ever more refined record of our biometrics, emotions, and behaviors. AI will enable governments and private companies to sort,

\footnotetext{
${ }^{1}$ For discussion of some of these issues, see, for example: https://www.nytimes.com/2020/03/01/busin ess/china-coronavirus-surveillance.html

https://www.abacusnews.com/china-tech-city/neighborhood-sends-drone-check-peoples-temperatur e-their-windows/article/3050608? ga =2.1627764444.1961446102.1592397993-253792852.1592397993 https://techwireasia.com/2020/04/can-ar-smart-glasses-help-china-identify-virus-carriers/

2 See, for instance,

Moscow's facial recognition tech will outlast the coronavirus https://www.youtube.com/watch ?v=pbGq3REp4PI.

https://theconversation.com/the-coronavirus-pandemic-highlights-the-need-for-a-surveillance-debat e-beyond-privacy-137060.

https://www.nytimes.com/2020/04/17/world/europe/coronavirus-france-digital-tracking.html.
} 
categorize, trade, and use biological data far more precisely than ever before. The unprecedented access of algorithmic networks to bodies, genomes, and minds will, she says, "create possibilities for social and bio-control that surpass Foucauldian concerns" (p.17).

What happens when we emerge from a post-COVID world? Will tech powers and personalized surveillance be de-escalated, or held in place for 'public protection'? The BioSocieties community has an important role to play in challenging digital exercises of state and corporate power.

\section{References}

Pauwels, E. (2019) "The New Geopolitics of Converging Risks: The UN and Prevention in the Era of AI," United Nations University Centre for Policy Research, 29 April 2019.

Filippa Lentzos is a Senior Research Fellow, with a joint appointment in the Department of Global Health \& Social Medicine and the Department of War Studies, at King's College London.

\section{What Am I Reading?}

\section{Todd Meyers}

\section{Department of Social Studies of Medicine, McGill University, Montreal, Canada}

What $\mathrm{I}$ am reading at the moment is a small effort to orient myself to whatever this moment is. The expatriate-novelist-protagonist, Luswage Amini, of Renee Gladman's Ravickian series--Event Factory (Dorothy, 2010), The Ravickians (Dorothy, 2011), Ana Patova Crosses a Bridge (Dorothy, 2013), and Houses of Ravicka (Dorothy, 2017) - is helping me come to terms with a world that resists translation. Kate Briggs's This Little Art (Fitzcarraldo, 2018), a book on literal translation from the translator of Roland Barthes's seminars at the Collège de France, shows me that the effort to translate can be a creative act, generative of new forms.

So much of the discussion these days is about control--being controlled, exerting control over a situation out of control. Julietta Singh's Unthinking Mastery: Dehumanism and Decolonial Entanglements (Duke University Press, 2018) reminds me that older forms of control do not recede in crisis, and our dissatisfaction with those forms must match their tireless agility and ugly inventiveness.

Absorbing loss and becoming accustomed to new ways of mourning are also themes on my nightstand. I started reading Sabrina Orah Mark's Wild Milk (Dorothy, 2018) after being awed by her powerful essay on parenthood, scholarship, and the failures of the academy in The Paris Review ("Fuck the Bread. The Bread is Over," May 7, 2020). Naja Marie Aidt's When Death Takes Something From You Give It Back, translated from Danish by Denise Newman (Coffee House Press, 2019) is a chronicle of mourning written in the aftermath of the sudden loss of her 
son, a book about reinhabiting the present as much as recollecting the past. Jenn Ashworth's Notes Made While Falling (Goldsmiths, 2019) is an unclassifiable book, at once an intimate story of traumatic childbirth and a critical work on worlds out of alignment. Ashon T. Crawley's The Lonely Letters (Duke University Press, 2020) and T Fleishman's Time is the Thing a Body Moves Through: An Essay (Coffee House Press, 2019) are both books that instrumentalize the body in ways that are often failing, sometimes erotic, but always aiming to grasp something, anything, about ourselves and others.

I have returned to dispatches from a different moment of crisis, a moment that never really passed. I find Paula A. Treichler's How to Have Theory in an Epidemic: Cultural Chronicles of AIDS (Duke University Press, 1999) endlessly instructive, now especially on ways we can continue to speak when the value of speech seems to be emptying out. And David Caron's The Nearness of Others: Searching for Tact and Contact in the Age of HIV (University of Minnesota Press, 2014), a book about proximity and the desire to touch and be touched is so relevant in the new age of social distancing and self-isolation.

I have been thinking about what comes next and what remains. Sarah M. Broom's The Yellow House (Grove Press, 2019) has me considering what possibilities there are in the return to origins, and what awaits us there. And finally, Susan Stewart's The Ruins Lesson: Meaning and Material in Western Culture (University of Chicago Press, 2020) gives me hope that even in aftermath there is something that grows:

"Perhaps, beyond disaster, we might discover in this history of ruins something ephemeral that is both significant and beautiful, something, as Wordsworth once said, "akin to life" that can guide us on to life. The this-worldly life of time and natural processes: the green weed breaking through the stone" (Stewart, 271).

Todd Meyers is Associate Professor and Marjorie Bronfman Chair in Social Studies in Medicine at McGill University.

\section{Total Bio/Geo/Politics}

\section{Jörg Niewöhner}

Institute of European Ethnology, Humboldt-Universität zu Berlin, Berlin, German

joerg.niewoehner@hu-berlin.de

A paper by Moreno Di Marco and his colleagues has been stuck in my mind for some time now. Published on February 25 2020, it was written about six weeks after the first cases of SARS-CoV-2 became public. I find it remarkable in at least three ways: first of all, it shows very poignantly the multiple links between emerging infectious agents, global environmental change and human health. Second, it estimates the economic impact of dealing with this virus to be higher than $\$ 150$ billion. (If that had proved to be the right order of magnitude, I would not be sitting at home writing these lines). Third, only a few weeks after I had read the paper, I heard German Chancellor Merkel addressing ministers from thirty different countries as 
part of the international Petersberg Climate Dialogue essentially delivering the core message of the paper. At a time, when most were expecting that looming health and economic precarity would push global environmental change off the agenda, Merkel clearly stated: if we do not get a grip on global land use change, these situations will keep on coming.

This is good news. In times of widespread anti-intellectualism, a head of state delivering state-of-the-art scientific knowledge in an important programmatic statement is a welcome relief. Appreciating complex relations and not losing sight of long-term goals in the midst of an acute crisis is to be commended.

Maybe I should stop here. Focus on the positive in times of gloom. Yet the paper warrants a closer look. In order to appreciate and manage the risks emerging from the multiple interdependencies of infectious agents, environmental change and human health, the paper argues for synergies, forms of leverage, and integration to optimize resilient governance. This is probably a good idea. Yet integration is only one possible response to globalized complexity. Appreciating practices of differentiation is another.

Worldwide, the persistent embodiment of the dominant political economy is leading to an Anthropogenic (Human) Biology: from arsenic and antibiotics to SARS and zoonosis - the externalities of our careless ways of living together are becoming embodied more and more deeply and with increasingly complex detrimental effects on our health. The notion of Anthropogenic Biology, which I first heard from Hannah Landecker, opens up multiple horizons. One of these consists of normalized landscapes that sustain normalized subjects: geo- and biopolitical modes of governance closing ranks through synergies and integration, a total geo/bio/politics. We need to make sure that other horizons are visible too: for example, by creating spaces for practices of differentiation that agonistically rub up against the efforts of integration. From the microbiome to planetary boundaries: "build back better" for the BioSocieties community must be about providing knowledge that helps to turn the upcoming debates into one of politics not management.

\title{
References
}

Di Marco, M et al. (2020). 'Opinion: Sustainable development must account for pandemic risk Proceedings of the National Academy of Sciences, 117(8), 3888-3892.

Jörg Niewöhner holds a Chair in Social Anthropology of Human-Environment relations at Humboldt University.

\section{Reading Trees}

\section{Carlos Novas}

Department of Sociology and Anthropology, Carleton University, Ottawa, Canada

\author{
CarlosNovas@Cunet.Carleton.Ca
}

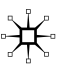


Peter Wohlleben's The Hidden Life of Trees and David George Haskell's The Songs of Trees provide a welcome escape from the confinement imposed by many weeks of quarantine and lockdown measures by transporting us into the complex ecosystems of forests and the unfolding lives of trees over decades. In their own ways, Wohlleben and Haskell seek to transform our understanding of trees as mere objects, or worse still, a standing reserve to produce timber or paper. To help us overcome the radical alterity that trees present to humans due to their immobile nature, their absence of a central nervous system or the slow pace at which their lives take place, both authors draw upon scientific research and personal observations to highlight the mutual entanglements between trees, fungi, bacteria, and other species that dissolve any ready distinctions between individual and collective in forest ecology. The rich and thick description of forest networks provided by Haskell and Wohlleben captivated me most as they brought to the forefront themes of the relationship between individuals (trees) and collectives (forests) as well as the tensions between competition and cooperation necessary for survival in often nutrient-poor environments.

An excellent example of how trees and forests wreak havoc on our neat classification systems is the "wood wide web"- a term unfamiliar to me prior to reading these books. The "wood wide web" is a vast underground fungal network that entangles mycelial filaments with tree roots enabling the exchange of sugars and minerals which each of these species requires to survive. This form of co-existence further enables trees to share resources and information with one another in a mutually beneficial fashion. Wohlleben and Haskell also describe how trees share information above ground as well. When trees come under attack due to insect infestations or herbivores eating their leaves, trees emit scents to warn other trees, thus enabling them to change the chemical composition of their leaves to make them less appetizing to predators. As such, both books invite us to pay as much attention to microscopic life beneath the roots of trees as to the forms of life dwelling under the forest canopy.

Although both books predominantly focus on forest ecosystems, they also dedicate attention to trees in urban environments. Wohlleben categorizes urban trees as "street kids" due to their loss of a nurturing, protective forest microclimate, in addition to the numerous challenges that face their development in densely populated cities. Haskell alternatively focuses on the important role that tree shade provides in mitigating the effects of urban heat sinks caused by global warming. He further documents how access to the cooling effects of trees is unevenly distributed across income levels and race in many cities around the world. Through sharing their deep understanding and appreciation of trees and forests, Wohlleben and Haskell invite us to think differently about all species and how they are all mutually entangled. Both books make for excellent reading during a global pandemic and for re-thinking how we care for these habitats on a local and global scale post-COVID-19.

\section{References}

Wohlleben, Peter (2016). The hidden life of trees: what they feel, how they communicate. Discoveries from a secret world (Vancouver: Greystone Books). 
Haskell, David George (2017). The songs of trees: stories from nature's great connectors (New York, NY: Viking).

Carlos Novas is Associate Professor of Sociology and Anthropology at Carleton University.

\section{Confined to My Flat, Reading An Apartment on Uranus}

\section{Anne Pollock}

Department of Global Health and Social Medicine, King's College London, London, $U K$

\section{anne.pollock@kcl.ac.uk}

The standout book of my lockdown reading has been Paul B. Preciado's An Apartment on Uranus (translated by Charlotte Mandell, Fitzcarraldo Editions 2019). The title essay is an elaborate meditation on the philosophical implications of queerness and transness; most of the rest of the sixty-nine essays that span the book's 275 pages take on such themes in short and easy to read bursts. Many were written as newspaper columns and blog posts-most originally in French, some originally in Spanish, now compiled in English.

The times and travels of the celebrity academic trans author provide the narrative arc: each essay is stamped with a date and a city. The opening essay is presented out of order (Athens 5 October 2018), but then we are taken back to 2013 Paris and the essays are presented chronologically, mostly from Paris and to a lesser extent Barcelona at the start, but then moving around: New York, Buenos Aires, Istanbul, Kiev, Athens, Beirut, Berlin, Turin, San Francisco, London, and more. An essay called "Identity in Transit" (Kassel 28 May 2016) takes place in the spaces of travel that seem exotic now because they are estranged from experience under lockdown: "the departure gate of an airport, or else at a border, at a hotel desk, at the counter for a car rental agency." For Preciado, who had at that point been taking testosterone but had not yet legally transitioned from female to male, showing his passport in these places often provokes the response: "This is not you!" To make it through the bureaucracy in such moments, Preciado invokes a far more essentialist notion of gender than the one he has learned from gender deconstruction, holding up a letter from a lawyer indicating that the female sex had been wrongly assigned to him at birth. He makes a provocative analogy with the refugee who seeks to be part of a new sovereign nation, "trans and migrant people are placed in the parodic position of asking to be recognized as subjects by those same State apparatuses that exclude and violently threaten them."

A cluster of essays toward the middle-end of the book are particularly relevant for readers of BioSocieties. An essay called "Chemical Condoms" (New York 12 June 2015) makes a comparison between the pre-exposure prophylaxis (PrEP) pill, Truvada, and the oral contraceptive pill; both, in contrast with condoms, reorder 
the body of the receptive partner molecularly so that the penetrative partner has no physical barrier to his sense of "completely sovereign 'natural' masculine sexuality." The molecularized biopolitical terrain described is evocative of Nikolas Rose, in a feminist intervention aimed toward a queer politic.

One of the last packed public events that I went to in person before the looming lockdown was the kind of thing to which Preciado often travels: a late February Conversation between Preciado and Jack Halberstam at London's Institute for Contemporary Art, as part of the tour to promote this book. I've 'attended' many talks under lockdown that follow a similar format-not precisely book talks but talks by authors of recently published books in conversation-but now with each speaker streamed into a box on a screen. None have had quite the feeling of an event, as this one did. Will events ever return?

I myself cross borders relentlessly, in ordinary times. Now, as is the norm for academics, I spend almost all of my time at home. Preciado still helps. His essay "Learning from the Virus," published in Art Forum, has been one of the few lockdown think-pieces that has been thought provoking for me. It opens: "If Michel Foucault had survived AIDS in 1984 and had stayed alive until the invention of effective antiretroviral therapy, he would be ninety-three years old today. Would he have agreed to confine himself in his apartment on rue de Vaugirard in Paris?" At a time when almost everyone else I knew seemed to be embracing lockdown life and flaunting their own strict adherence to bodily isolation as if submitting to the dominant biopolitical order were suddenly uncomplicatedly good, Preciado was already attentive to the fraught biopolitical stakes. I'll keep reading.

\section{References}

Preciado, P.B. (2020). An Apartment on Uranus. Translated by Charlotte Mandell. Fitzcarraldo Editions, London.

Anne Pollock is Professor of Global health and Social Medicine at King's College London

\section{Against 'Mental Health'}

\section{Nikolas Rose}

Department of Global Health and Social Medicine, King's College London, London, $U K$

\section{Nikolas.Rose@kcl.ac.uk}

"No more awareness, please!" is the cry from one a leading UK psychiatrist every time we enter the annual Mental Health Awareness Week. He is in a minority. Nowhere has this been clearer than in the time of the pandemic. During the 
lockdowns imposed in so many countries, our lives have been discombobulated, our habits thrown into confusion, our news filled with images of suffering and death, our loved ones facing the prospect of a horrid and potentially fatal illness, our neighbors masked like old-time outlaws, our lives confined and constrained as never before, our futures thrown into doubt. Many of us, not least those whose lives are already tough, are anxious, sad, worried, miserable, angry, scared, exhausted, stir crazy, lonely, troubled, distressed, perturbed, apprehensive, occasionally dejected, sometimes terrified as our meager financial resources melt away before our eyes. But this language of the emotions seems not enough. What is at stake, it seems, is our mental health. The newspapers are full of stories about those experiencing mental health problems, charities and experts give us advice on how to manage our mental health, exercise gurus frame their injunctions to stretch, jump, run, and so forth, not just for the good for our locked-in bodies, but because they are good for our mental health. Awareness is all. Once we are aware that the feelings we are experiencing are mental health problems, once we can speak openly about these mental health problems to family, friends, and employers, we are en route to a solution. No stigma, no shame-who could not welcome the fact that mental health has come out of the shadows?

It is a brave psychiatrist who would be 'against awareness' during this pandemic. Most predict nothing less than a tsunami of mental health problems. Lockdown children are of particular concern. Did you think that kids were dragged unwillingly to school, yearning for liberation at the end of the school day, and the freedom of the holidays? Not so. 100 specialists in psychology, mental health, and neuroscience, in a letter published in The Sunday Times, predict that loneliness and isolation during school closures could permanently damage children's mental health, and urge government ministers to release kids back to the salutary benefits of school (Roxby, 2020).

Adults too: did you think that many people might actually enjoy being spared the arduous daily ritual of the commute to and from work? Not so. Psychologists, psychiatrists, and epidemiologists are busy charting our pandemic moods; their surveys report increased anxiety and sadness during the 'lockdown' (Fancourt, Steptoe, and $\mathrm{Bu}, 2020 ; \mathrm{Banks}$ and $\mathrm{Xu}, 2020$ ). Despite findings that are ambiguous at best, authors usually conclude that "greater efforts need to be made to help individuals manage their mental health during the pandemic" (Fancourt, Steptoe, and $\mathrm{Bu}, 2020)$. More research is needed.

Did you think it might be distasteful to regard a global pandemic as a great opportunity for research grants? Not so. A multi-authored paper in Lancet Psychiatry calls for action from 'mental health science' to collect "high-quality data on the mental health effects of the pandemic across the whole population and vulnerable groups, and on brain function, cognition, and mental health of patients with COVID-19." There is "an urgent need" for research funding agencies to stump up to help develop what are bizarrely termed "mechanistically driven interventions" to address "the psychological, social, and neuroscientific aspects of the pandemic" (Holmes et al., 2020).

Did you think that dynamically inspired therapists might learn from Freud's modest claim that psychoanalysis offered only to transform hysterical misery into 
common unhappiness? Well, not quite. Under a headline warning that another pandemic looms, this time for our psychological health, feminist psychotherapists, trauma therapists, and grief counsellors-some of whom, we are told, are bestselling authors-predict long-term consequences, especially for those who have had past experiences of trauma: "the psychological fallout of the pandemic will be a huge and protracted challenge for an overstretched and underfunded health system" (O’Hagan, 2020).

Who could be 'against mental health'? Who would minimize the stress encountered on a daily basis by health workers forced to practice in exhausting and dangerous conditions without protective clothing, with so many patients in peril of death? Who could doubt the strain on people in cramped apartments, juggling the demands of children, domestic responsibilities, work? Who could doubt that social isolation is sometimes hard to bear, especially for single mothers or those who are elderly or dependent? Who could fail to recognize the apprehension of front-line workers carrying on emptying bins, delivering parcels, driving taxis and buses despite the pandemic. But are they experiencing 'mental health problems'? Are they 'at risk' of mental illness? Are their feelings actually 'symptoms' that may, if not attended to, become 'mental disorders'? Are these experiences of anxiety, trepidation, despondency even anguish matters of 'health' at all? Should we think of them in the terms of the Convention on the Rights of Persons with Disabilities: psychosocial disabilities, which restrict those who experience them from full social participation? Should our guide be the World Health Organisation, which defines mental health as "a state of well-being in which every individual realizes his or her own potential, can cope with the normal stresses of life, can work productively and fruitfully, and is able to make a contribution to her or his community"? Would that not classify about $90 \%$ of the world's population as lacking mental health? But if we decide that these are not matters of health, what about the problem of comorbidities, the intertwining of diseases such as diabetes, coronary heart disease, metabolic disorders with these very feelings of anxiety and depression, leading to calls for the treating physician to regard them as part of the same 'syndrome'? (Barnett et al., 2010). Would it not be better to think of the distress of body and soul experienced by those forced to make their lives in the face of the consequences of structural inequality in terms of 'social suffering'? (Kleinman, Das, and Lock, 1997).

How can it be, after half a century of researching the history of psychiatry and its institutions, of teaching about mental health and society, of living with someone with a severe and enduring mental disorder, that I do not know the answer to these questions? After three months of intensive reading about mental health during the pandemic, I am more confused than ever. I know people with psychotic depression, bipolar disorder, with diagnoses of post-traumatic stress disorder and schizophrenia. And whatever they experience, it is not what has come to be termed 'a mental health problem.' So, no, don't obscure these by folding them into an all embracing narrative of mental health. Less awareness please, less transmutation of despondency, apprehension, unease, uncertainty, and the manifold ailments of being human in a profoundly unjust world into problems of mental health. Yes, I am against 'mental health.' 


\section{References}

Roxby, P. (2020). Coronavirus: Child psychologists highlight mental health risks of lockdown.' BBC News. https://www.bbc.co.uk/news/health-53037702

Fancourt, D., A. Steptoe, and F. Bu (2020) 'Trajectories of depression and anxiety during enforced isolation due to COVID-19: longitudinal analyses of 59,318 adults in the UK with and without diagnosed mental illness.; medRxiv: https://doi. org/10.1101/2020.06.03.20120923

Banks, J. and X. Xu. (2020) The mental health effects of the first two months of lockdown and social distancing during the Covid-19 pandemic in the UK. 2020, Institute for Fiscal Studies: London.

Holmes, E.A., et al. (2020) 'Multidisciplinary research priorities for the COVID19 pandemic: a call for action for mental health science' The Lancet Psychiatry 7 (6): 547-560.

O'Hagan, S. (2020) 'Health Experts on the Psycholgocial Costs of COVID-19.' The Guardian. https://www.theguardian.com/world/2020/jun/07/health-experts-onthe-psychological-cost-of-covid-19

Barnett, K., et al. (2012). 'Epidemiology of multimorbidity and implications for health care, research, and medical education: a cross-sectional study.' The Lancet, 2012, 380 (9836): 37-43.

Kleinman A, Das V, Lock M, (1997). Social Suffering. Berkeley, CA: University of California Press.

Nikolas Rose is Professor of Sociology in the Department of Global Health and Social Medicine at King's College London.

\section{When the City Comes to Life}

\section{Chloe Silverman}

Center for Science, Technology \& Society and Department of Politics, Drexel University, Philadelphia, USA

cbs78@drexel.edu

In mid-March, I ordered a pile of books from our local bookstore, which had begun offering home delivery. I've only gotten to one of them: N.K. Jemisin's The City We Became. In the novel, cities come to life when they achieve maturity and are materialized in the form of human avatars who act as their protectors. I love Jemisin's imagination and humor, and I love the way that even I, an indifferent reader of fantasy and science fiction, can see how she grapples with the legacies of a genre which also has a history of significant racism and xenophobia. In this case, as Jemisin herself explained to an interviewer, she played with the writing of 
H.P. Lovecraft, a virulent racist whose stories also influenced generations of authors. In Jemisin's book, New York battles one of Lovecraft's monsters, which takes out the Williamsburg Bridge. New York is injured in the process. The avatars of the five New York City boroughs (Manhattan, Brooklyn, the Bronx, Queens, and Staten Island) must find each other and, despite their occasional suspicion and dislike of each other, unite in order to save him and defend the city.

In Lovecraft's fantasies, evil comes from the outside and those most susceptible to its allure are those that Lovecraft viewed as less civilized. The monsters in Jemisin's book are insidious and, in their attacks on the five boroughs, cunning. Raffi Khatchadourian (2020) notes that Jemisin referenced her own experiences of harassment in writing how the creatures muster an army of "alt-right trolls to assist them, and the protagonists gird against cyber-harassment." One citizen films the avatar of Manhattan and his new roommate, who is trans, on her iPhone, accusing them of committing obscene acts in public; Staten Island's controlling and abusive father invites a swastika-tattooed misogynist into their home, who then attacks her.

This made me curious, so I downloaded and read Lovecraft's "The Call of Cthulu," first published in 1926. It was all there, the shadowed light, non-Euclidean alien architecture, "Eldrich abominations," unspeakable names, and slumbering horrors. Reading the story helped me better appreciate what Jemisin was doing by repurposing Lovecraft, whose bigotry and white supremacy are right there in the first pages of the story, but whose influence must be hard for any fantasy writer to escape. I hadn't realized how his creations populated so many familiar tales. I enjoyed reading the story, but I enjoyed it more for knowing what Jemisin had made of it, and how she teaches us take more responsibility for the myths that animate all kinds of writing.

In contrast to Lovecraft's submerged and utterly alien evil that is worshipped or feared because of its incomprehensibility, all the creeps in Jemisin's New York were primed for takeover-they work with the beast because they were already collaborating. It is their smug superiority and comfort with existing habits of violence (racism and homophobia, oppressive policing, gentrification) that are further weaponized by the interdimensional monsters. The creatures plotting to destroy the city are scary because to the already impressionable, they look "decent," nice, and friendly, and they have been there all along. A beloved local burger joint is razed for condominiums: "This didn't just start when the city came to life," growls the Bronx, scanning a construction permit (p. 357).

I finished reading the book while teaching Virginia Eubank's fantastic Automating Inequality (2017) to an introductory undergraduate course. We read about systems designed with superficially optimistic intentions that punish poor families for seeking public support and services. One algorithm developed for use in Pennsylvania categorizes parents using public services as more likely to be negligent or abusive (pp. 156-157); another in Indiana treated paperwork mistakes by Medicaid applicants as evidence of a "failure to cooperate" (pp. 41-43). And yet, with their promise of "innovation and transparency" it's easy to see how governments get seduced by these programs, which seem to those not pursued, surveilled, and targeted by them to be well-intentioned and, well, decent. 


\section{References}

Eubanks, Virginia. 2017. Automating Inequality: How High-Tech Tools Profile, Police, and Punish the Poor. New York: St. Martin's Press.

Jemisin, N. K. 2020. The City We Became. New York: Hachette Book Group.

Khatchadourian, Raffi. 2020. "N.K. Jemisin's Dream Worlds". The New Yorker, January 27th, 2020. https://www.newyorker.com/magazine/2020/01/27/nk-jemisinsdream-worlds (accessed 20 June 2020).

Lovecraft, H.P. 1926. "The Call of Cthulu”. Internet Archive. https://archive.org/ details/TheCompleteWorksOfHPLovecraft_201412/page/n237/mode/2up (accessed 18 June 2020).

Chloe Silverman is Director of the Center for Science, Technology \& Society at Drexel University

\section{Imperial Environments}

\section{Hallam Stevens}

School of Humanities, Nanyang Technological University, Singapore

\section{hstevens@ntu.edu.sg}

William Dalrymple's new book about the rise of the English East India Company (EIC), The Anarchy, is most explicitly a warning about the perils of rampant capitalism: "The 300-year old question of how to cope with the power and perils of large multinational corporations remains today without a clear answer: it is not obviously apparent how a nation state can adequately protect itself and its citizens from corporate excess" (p. 395). The bailouts and bribes that sustained the EIC seem strikingly relevant in an age of growing corporate power. Multi-national corporations-especially Internet titans like Facebook and Alibaba-are, like the EIC, now more powerful and influential than many states.

But the narrative also reveals some perhaps more subtle lessons about genesis and maintenance of a global empire that ultimately depended on environmental conditions, on the one hand, and a distinctive racial biopolitics, on the other. The Anarchy has little to say directly about India's environment, natural resources, or geographic conditions. But it is surely significant that the events that most nearly stopped the EIC's rise in its tracks - the Bengali famine that began in 1769-was partially a "natural" disaster, caused by a confluence of EIC greed and environmental conditions (particularly weather). The famine killed about ten million people. It also not only caused the value of the company to plummet, but instigated a long road of parliamentary investigations that, eventually, brought the company increasingly under the control of the British Crown.

But the famine also precipitated a chain of events that showed how entangled EIC's history is with global developments for Britain and some of its other colonies. Much of Dalrymple's book is an almost micro-historical account of the battles and 
back-room deals that cemented the company's dominant position in the subcontinent. But the narrative is at its best when it is able to step back and make broader, global historical connections. One of the indirect effects of the Bengali famine, for example, was the 1773 Tea Act—an attempt by the British parliament to protect the EIC's fortunes by selling and taxing EIC tea in the American colonies. As is well known, American colonists, in turn, responded by dumping the tea into Boston harbor.

The revolution that was provoked in part by EIC tea was lost in 1781 when the then Earl Cornwallis surrendered to George Washington at Yorktown. By 1786, Cornwallis had been dispatched to Calcutta as governor of Bengal. His job was to make sure that the Indian colonies did not go the way of the American ones. Although, again, The Anarchy, to its detriment, is hardly a book about race, ethnicity, or religion, the lessons Cornwallis took from America were remarkably biopolitical: "[He] was determined to make sure that a settled colonial class never emerged in India to undermine British rule as it had done, to his own humiliation, in America" (p. 327). In practice, this meant severely restricting the rights of any AngloIndians (children born from unions between British men and Indian women). This "unembarrassedly racist legislation" disqualified them from owning land, or serving in the military or civil service. This entanglement of corporate avarice with ideas of racial supremacy had even more enduring long-term effects than the EIC's more manifest forms of violence, corruption, and coercion.

Even in a popular book on empire that is unashamedly focused on men, machinations, and military power, the role of both environment and the biopolitics of race in these stories lies barely concealed beneath the surface.

\section{References}

Dalrymple, William (2019). The Anarchy: The Relentless Rise of the East India Company. London: Bloomsbury 2019.

Hallam Stevens is Associate Professor in the School of Humanities at Nanyang Technological University

\section{Pox Americana: Reflections on Octavia Butler's Parable of the Sower}

\section{Banu Subramaniam,}

Women Gender, Sexuality Studies, University of Massachusetts, Amherst, Amherst, United States

banu@wost.umass.edu 
In Octavia Butler's eerily prescient 1993 novel, Parable of the Sower, the apocalypse or the "Pox" rages in the United States from 2015-2030. With no government to help, its citizens live in constant fear. Traveling is dangerous; people learn to hunt and defend themselves. It is a ruined dystopic scene where anarchy and exploitation reign. Butler lays out a world that feels palpably familiar-the ravages of inequality seethe, climate change consumes its landscapes, and a greedy and heartless plutocracy puts profits before people. It is a bleak world. The brilliance of Butler's work, as so many have noted, is her choice of "mundane" science fiction, a genre not immersed in fantasy, intergalactic travel, or weird looking aliens (who surprisingly eat with forks and knives!). Butler's work instead forces us to face the inevitable progression of our own world-not hundreds of years into the future, but in our lifetime. Her work brings an urgency that is inescapable.

What a time to re-read this novel and its sequel Parable of the Talents (1998)! Butler's tales that speak to afro-futurism and afro-pessimism feel prescient because we have our own raging pox (COVID-19) that has exposed our own fragile and withering public infrastructure of government, healthcare, law enforcement, and judiciary. In the last four years, we, in the United States have watched the delusion of a Pax Americana devolve into a contemporary Pox Americana, an era that feels uncannily similar to the novel's "pox," including an increasingly religiously radicalized government. In each page, one faces that sickening and sinking feeling of recognition.

However, what could be utter despair, isn't. Butler exposes the horrifying legacies of the violence of slavery, colonialism, and capitalism, but also offers us a wonderfully powerful character Lauren Olamina, a young Black girl who follows Earthseed, a book of teachings she "discovers." As a character in the book remarks, it is "some combination of Buddhism, existentialism, Sufism," (239) elaborating a philosophy of community, ecology, and ethics in Lauren's quest for a more just and equitable future. Her road is torturous, and the journey difficult, but it is roadmap of how we may reckon with our past and future.

Butler's vision is grounded in the centrality of change, enshrined in Earthseed, a secular theology grounded in the importance of change-no nativist fantasies of the ancients or a return to an idyllic Eden here. As Earthseed proclaims: All that you touch is Change/All that you Change Changes you/The only lasting truth Is Change/ God is Change. (3)

Calls for change are in the air. As the protestors across the United States (indeed the world) insist, if we are to seek a viable future, the time is now. We need to rout the entrenched anti-blackness that pervades our system. As youth movements remind us, we have brutalized not only black communities, other communities of color, immigrants, refugees, but also our planet and co-inhabitant species. As the American bunker-in-chief spews insults from his walled fortress, the business of the American people continues to be run by lobbyists of the rich and powerful. It is time for a global reckoning. Butler's future vision in the character Lauren urgently reminds us-Step aside, it is time for black women-to teach us about leadership and fellowship. Their enduring survival and abiding wisdom might be our only hope for life in the ruins. Read, or re-read this book. It is a book for our times. 
Acknowledgments: thanks to Sushmita Chatterjee, Katrina Karkazis, and Natali Valdez for their feedback.

\section{References}

Butler, Octavia E. (1993). The Parable of the Sowers. Griot Editions

Butler, Octavia E. (1998). The Parable of the Talents. Griot Editions

Banu Subramaniam is a Professor of Women Gender, Sexuality Studies at the University of Massachusetts, Amherst

\section{Viral Methods}

\section{Ayo Wahlberg}

Department of Anthropology, University of Copenhagen, Copenhagen, Denmark

ayo.wahlberg@anthro.ku.dk

Apparently 'pestilence fiction' has been booming-Margaret Atwood, Ling Ma, Hanne-Vibeke Holst, Albert Camus, Dean Koontz, Michael Crichton, Stephen King. At the height of the European COVID-19 pandemic back in March (which is not over in any way), I remember reading Francesca Melandri's letter from the future in the Guardian ("A letter to the UK from Italy: this is what we know about your future," 27 March 2020) in which she wryly informed those of us who had just embarked on lockdown life "First of all, you'll eat. Not just because it will be one of the few last things that you can still do... You'll pull apocalyptic literature out of your bookshelves, but will soon find you don't really feel like reading any of it. You'll eat again." She nailed it. I did eat and I did download a copy of The Plague and plowed through it on my iPad, once again confirming that I'm just never going to enjoy reading books on a gadget. And, as Melandri predicted, I left it at that. Although, not quite.

One of the few perks of the time-consuming peer reviewing that we all do is that quite a few publishers will offer you books up to a couple hundred dollars from their catalogue if you review a book manuscript. That or a cash cheque. I tend to go for the books and as a result, when Denmark was sent into lockdown on the $11^{\text {th }}$ of March, I had a stack of unread books on my desk. In haste, I grabbed about ten, which included Simukai Chigudu's The Political Life of an Epidemic: Cholera, Crisis and Citizenship in Zimbabwe (Cambridge University Press, 2020), Katherine Mason's Infectious Change: Reinventing Chinese Public Health after an Epidemic (Standford University Press, 2016), and Theresa MacPhail's The Viral Network: A Pathography of the H1N1 Influenza Pandemic (Cornell University Press, 2014). Apart from sharing the craft of writing, these three scholars show us in their superbly researched studies of SARS in China, 
cholera in Zimbabwe, and H1N1 globally that ethnographically grounded yet expanded methodologies are required if we are to come to empirical grips with such complex phenomena as highly contagious bacteria and viruses. Within anthropology, many descriptors have emerged over the past couple of decades to account for these new ways of doing ethnography: from multi-sited ethnography, to non-local ethnography, pathography and what I have called assemblage ethnography in my studies of reproductive technologies in China (Wahlberg 2018).

In reading Chigudu, Mason and MacPhail, I was struck once again by the commonalities between such approaches to studying complex biological phenomena (e.g., bacteria, viruses, infertility); all are deeply rooted in political economies and structures of governance and scientific networks, which in turn (and together with the biological phenomena) shape lived experience and vice versa. Having interviewed 125 people to learn from their stories and experiences, Chigudu argues "the telling of stories is always a political act and, in this way, stories are an especially illuminating prism through which to explore the politics and social contours of the cholera outbreak and its aftermath" (p.23). But, precisely as an attempt to assemble many different kinds of materials, Chigudu also interviewed government officials and amassed "an extensive catalogue of documentary sources" (p. 27) including media articles, technical reports, and scientific studies on the cholera outbreak. For her part, Mason explains how "in focusing on a local government system in the most powerful non-Western country in the world as a critical node in a global network of disease control, this book decenters the dichotomous relationship between powerful Western actors and victimized non-Western locals presented in much of the ethnographic literature on global health" (p. 32). And, finally MacPhail argues that "pathography takes a disease, illness or crisis - and its attendant stories - as its grounding object" as she sets out to ethnographically trace H1N1's viral network understood as "any group of individuals, institutions, technologies and other living and nonliving things that are interconnected in an exponentially expanding web of knowledge and information-sharing" (p. 6, 14).

Just as anthropology has influenced and shaped STS profoundly, not least via its ethnographic methods and troubling of nature-culture boundaries, here we can see the lasting effects of STS (and the Foucauldian concept of problematization I would hasten to add) on anthropology. Ethnography has been reshaped, not into laboratory ethnography, but rather into an assemblage that tracks how political economies, scientific expertise, forms of governance, and lived experience intersect around and (co-)produce a certain phenomenon or problem. Whatever we end up calling such methodologies, they are clearly 'going viral.' And, for pandemic reading, I can wholeheartedly recommend all three of these books, not only because of their clear relevance for thinking about COVID-19, but also for the contributions they have made to helping us improve our research practices when we take a biological phenomenon (e.g., vibrio cholerae, H1N1 virus, or SARS) as the object of our social study. 


\section{References}

Chigudu, S. (2020) The Political Life of an Epidemic: Cholera, Crisis and Citizenship in Zimbabwe. Cambridge University Press.

MacPhail, T. (2015). The Viral Network: a Pathography of the H1N1 Influenza Pandemic. Cornell University Press.

Mason, K. (2016). Infectious Change: Reinventing Chinese Public Health after an Epidemic. Stanford University Press.

Wahlberg, A. (2018). Good Quality: the Routinization of Sperm Banking in China. University of California Press

Ayo Wahlberg is a Professor of Anthropology at the University of Copenhagen

\section{Feeling Angry}

\section{Elizabeth A Wilson}

Department of Women's, Gender, and Sexuality Studies, Emory University, Atlanta, USA

\section{e.a.wilson@emory.edu}

I started reading manifestos early in the spring of 2020. Feminist and anti-capitalist manifestos, anti-racist and artistic manifestos, manifestos for the mad, for nationalist movements, for animal rights, and for digital futures. I am interested in the manifesto form because I am working on Valerie Solanas. Her SCUM Manifesto is a remarkable document of rage and joy and destruction: "Life in this society being, at best, an utter bore and no aspect of society being at all relevant to women, there remains to civic-minded, responsible, thrill-seeking females only to overthrow the government, eliminate the money system, institute complete automation and destroy the male sex" (p. 37)

As spring 2020 wore on, the genre of the manifesto (short, loud, angry, futureoriented) began to feel more and more relevant. First, the COVID-19 outbreaks and lockdowns in multiple countries in March; then the widely publicized police killings of Breonna Taylor (in March in Louisville, KY), George Floyd (in May in Minneapolis, MN), and Rayshard Brooks (in June in Atlanta, GA) and the intensification of Black Lives Matter protests that followed; and now voter suppression in my home state of Georgia in June and a presidential election looming in November. As I write this, in the late spring of 2020, it is not clear what lies ahead. A manifesto seems well suited to these threadbare circumstances of death and uncertainty and social duress.

One of the crucial questions posed by manifestos is what to do with negative affects: anger, hatred, fear. Is an angry manifesto working in the service of social transformation or does it want (as the title of Breanne Fahs' anthology of manifestos 
suggests) to simply burn it all down? The primary function of anger, Silvan Tomkins claims, is to "make bad matters worse and further to increase the probability of an angry response" (p. 115). It has been common in feminist texts to see anger figured as a restorative event: under the right conditions, or in the right hands, anger will lead to clarity and empowerment. I am less sure. I wonder if the appeal of anger, in a manifesto or on a street, is that it makes a bad set of circumstances more noxious. Part of what makes anger so compelling is that it pushes me (and those around me) beyond what is tolerable with no promise of catharsis, or clarity, or a way forward. It seeks the intensification of wretchedness, destruction, ugliness, and pain. If that is the case then the function of anger inside feminism may need reconsideration. Ti-Grace Atkinson saw this early: "Sisterhood is powerful" she is alleged to have said "it kills sisters" (Joreen 1976, p.92). Maybe anger in response to misogyny also carries with it the capacity to damage the people and places and ideas that feminism holds dear. If this damage is unavoidable and non-trivial then we are going to need a less idealizing account of what feminist anger does. Manifestos like SCUM help me see how anger-surely a feeling essential to any political action-resists our attempts to contain and control it.

With that in mind, and in no particular order, here are some words I have been reading in this moment of lethal anger and disquiet: "I want a person with aids for president and I want a fag for vice president and I want someone with no health insurance and I want someone who grew up in a place where the earth is so saturated with toxic waste they didn't have a choice about getting leukemia" (Zoe Leonard, I Want A President, 1992, np); "Assimilation, born of fear and timidity, always ends in contempt and hatred. It carries within it the germs of struggle. The struggle of self against self, that is to say, the worst of struggles" (Aimé Césaire, Négreries: Black Youth and Assimilation, 1935, p. 31); "A whole imperial project of diversion, interference, and polarization of bodies... Over time, and via so many combined effects, THEY ultimately obtain the desired disarmament-in particular immuno-disarmament-of bodies" (Tiqqun, Preliminary Materials for a Theory of the Young-Girl, 2012, p. 12-13); 'I'm angry. I'm angry for being condemned to death by strangers... It is cruel and vile and meaningless and everything I have in me rails against the absurdity" (ACT UP, Queer Nation Manifesto: Queers Read This, 1990, np); "This time we are going all the way" (Redstockings, Redstockings Manifesto. 1969, np).

\section{References}

ACT UP. (1990). Queer Nation Manifesto: Queers Read This. In: B. Fahs (ed) Burn it Down! Feminist Manifestos for the Revolution. London: Verso, pp. 28-40

Césaire, A. (1935). Négreries: Black Youth and Assimilation. In: J. Lack (ed) Why are we 'Artists'? 100 World Art Manifestos. Harmondsworth: Penguin, pp.29-32.

Fahs, B. (2020). Burn it Down! Feminist Manifestos for the Revolution. London: Verso.

Joreen. (1976). Trashing: The Dark Side of Sisterhood. $\underline{M s}$. April, pp.49-51, 92-98. 
Leonard, Z. (1992). I Want A President. In: B. Fahs (ed) Burn it Down! Feminist Manifestos for the Revolution. London: Verso, pp. 27.

Redstockings. (1969). Redstockings Manifesto. In: B. Fahs (ed) Burn it Down! Feminist Manifestos for the Revolution. London: Verso, pp. 207-209.

Solanas, V. (1971/2015). SCUM Manifesto. London: Verso.

Tiqqun. (2012). Preliminary Materials for a Theory of the Young-Girl. New York: Semiotexte.

Tomkins, S. (1991). Affect Imagery Consciousness. Volume 3. The Negative Affects. Anger and Fear. New York: Springer.

Elizabeth A. Wilson is a Samuel Candler Dobbs Professor in the Department of Women's, Gender, and Sexuality Studies at Emory University.

Publisher's Note Springer Nature remains neutral with regard to jurisdictional claims in published maps and institutional affiliations. 